\title{
Oscillating wave energy power generator for lift net fishing boat
}

\author{
Luther Sule $^{1}$, Parabelem Tinno Dolf Rompas ${ }^{2}$ \\ ${ }^{1}$ Department of Mechanical Engineering, Universitas Hasanuddin, Indonesia \\ ${ }^{2}$ Department of Informatics Engineering, Universitas Negeri Manado, Indonesia
}

\begin{tabular}{l}
\hline \hline Article Info \\
\hline Article history: \\
Received Jul 29, 2018 \\
Revised Sep 15, 2018 \\
Accepted Sep 28, 2018 \\
\hline
\end{tabular}

Keywords:

Lamp

Makassar strait

Net fishing boat

Oscillating wave

Power generator

\begin{abstract}
This paper compares several designs of an oscillating wave power generator suitable for local net fishing boat in the waters of Tonyaman in the Strait of Makassar, Indonesia. The designs were based on wave height data for the period of January to December 2016 and of the local fishing vessel construction data. Several generator designs were created to replace diesel engines used by the local fishermen to power their boats' lamps in the night. Results showed that DESIGN 5 with Arm length to buoy (L1) of $4 \mathrm{~m}$ and Arm length to pulley (L2) of $3 \mathrm{~m}$ and DESIGN 6 with L1 of $4 \mathrm{~m}$ and L2 of 2 $\mathrm{m}$ were the two designs most fitting for that purpose. Both designs could produce sufficient power $(\mathrm{P})$ to power the boats' lamps in the shortest wave height condition $(0.75 \mathrm{~m})$ and the tallest wave height condition $(1.5 \mathrm{~m})$. At the shortest wave height condition $(0.75 \mathrm{~m})$, DESIGN 5 produced $14,237.58$ $\mathrm{W}$ and DESIGN 6 produced 14,290.31 W. At the tallest wave height condition (1.5 m), DESIGN 5 and DESIGN 6 generated 28,285.31 W and $28,496.25 \mathrm{~W}$ of power, respectively.
\end{abstract}

Copyright $\left({ }_{0} 2019\right.$ Institute of Advanced Engineering and Science. All rights reserved.

\section{Corresponding Author:}

Luther Sule

Departement of Mechanical Engineering,

Universitas Hasanuddin,

Jl. Poros Malino Km 6, Bontomarannu 92171, South Sulawesi, Indonesia.

Email: luther.sule@unhas.ac.id

\section{INTRODUCTION}

Indonesia is an archipelago state with nearly $60 \%$ of its territory is sea water with the total coastline of 99,093 km surrounding 17,000 islands, 9,000 of which are unreachable by current methods of power generation [1-2]. With such a long coastline, wave energy potential is significant and if properly utilized [3], it could become a very large source of energy. Indonesia's wave energy practical potential is estimated about 17.989 MW [4].

Ocean energy is a non-biological, renewable energy source with a great potential for development in Indonesia [5-6]. Besides being an important source of food, the ocean is also a potential source of energy, the role of which will only become increasingly significant in anticipation of the total depletion of conventional energy sources and the increase need of energy [3]. It is estimated that the ocean has the potential to provide four times the global demand of energy, and several developed countries are pursuing research and development on the topic both at the experimental and commercial scales [7].

Fishermen in Tonyaman waters use lift net boats that are powered by two engines: a primary engine propelling the boat and a second engine powering the lights that attract the fish. This second engine is usually powered by diesel. The continuous consumption of diesel could give rise to an energy crisis. Energy crises occur as a result of the increasing rarity of crude oil and the increasing demand for energy. A breakthrough in alternative, renewable energy sources is increasingly necessary [8]. Possible alternative energy source that could be the solutions for this looming crisis is ocean wave that has been known for a long time as a vast source of energy [9-10]. 
Wave energy is the most suitable of renewable energy options for the topographical conditions of the area of Tonyaman waters. One such type of wave energy generator that might be used to replace diesel power is an oscillating wave generation system. Oscillating wave energy power generators convert the rise and fall of sea waves into rotary movement that is transferred to a generator to produce electricity [11-12]. Such system is environmentally-friendly because its construction and operation do no inflict damage to the natural ecosystems. There are several published articles that cover the topic of power generation using wave energy in many regions throughout Indonesia [4], [10]. Such articles inspired the writer to design an oscillating wave energy power generator that can be installed on the boats of fishermen in the waters of Tonyaman in Makassar Strait of Indonesia.

\section{DESIGN OF OSCILLATING WAVE ENERGY POWER GENERATORS}

Oscillating water columns are so called because they utilize the oscillation of a floating object in water (buoy). This oscillation of ocean waves produces a rise and fall motions of the buoy that is transferred to a generator.

\subsection{Oscillating Water Column Components}

The components of oscillating water column e.i. float/buoy, drive shaft, pulley and sprocket, generator DC, battery, and transformer [12]. The rise and fall of ocean waves move the buoy. This movement is transferred to the drive shaft. The buoy must have a density lower than the water it is placed into. The drive shaft is made up of two arms: the first arm is located near the buoy and the second arm transfers the rise and fall motion of the buoy to the sprocket to be converted into rotary motion. A pulley and sprocket system is used to convert the rise and fall motion from the drive shaft into rotary motion. A generator is a machine that converts mechanical energy into electrical energy. The electricity generated could be AC or DC depending on the generator. In this case, a DC generator was used to charge the battery powering the lighting systems [13] on Tonyaman fishing boats. The battery (car battery) is an electrical cell in which reversible electrochemical reactions can occur with high efficiency. The battery stores electrical energy in the form of chemical energy. The battery supplies power to the starter system, ignition system, lights and other electrical components. A transformer is a static electric machine that increases or decreases the voltage and current of a power system or electrical circuit. Transformers are made up of several important components: the iron core, primary coil (NP), secondary coil (NS), and supporting components. The iron core of a transformer carries the magnetic flux $(\Phi)$ produced by the primary voltage (VP) resulting in a secondary voltage (VS). Supporting components of a transformer serve to bolster performance and can include protection systems, cooling systems, and other such components depending on the capacity of the transformer.

\subsection{Working Principle of an Oscillating Wave Energy Power Generators}

Figure 1 shows the oscillating water column systems [14]. Input of ocean wave movement that transferred by the float/buoy to the drive shaft (moment arm), rotation in the sprocket and pulley automatically works based on the movement of the moment arm. Rotation in the DC generator generating the power that charges the battery and output of voltage and current generated by the DC generator and transferred to a buck boost converter. Rotary motion in the pulley is connected to the DC generator that converts mechanical energy into electrical energy. The addition of a transformer and converter controls the energy output by the DC generator, ensuring that the voltage and current stay at the necessary values.

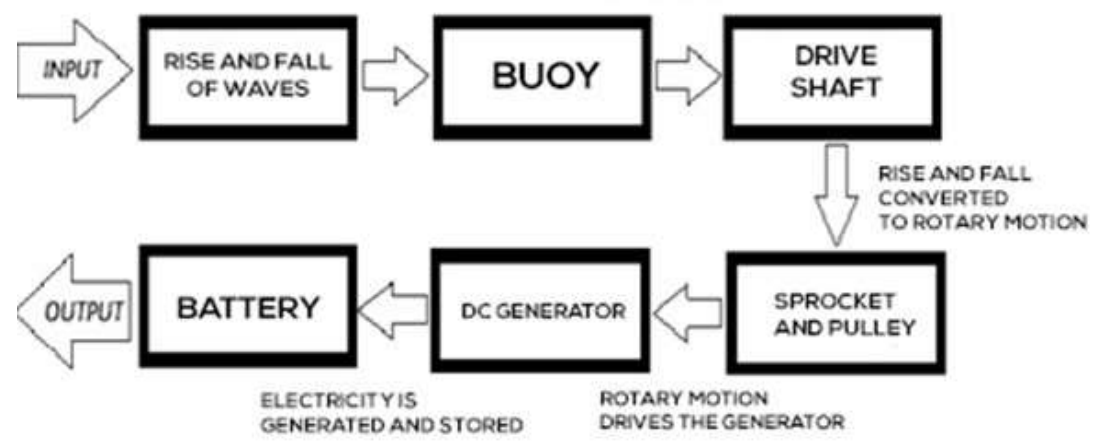

Figure 1. Block diagram of oscillating wave energy power generator 


\section{METHODS}

The data collection of wave height conducted in Pajalele waters of Pinrang regency South Sulawesi which is a fishing base within one year period (January-December 2016). The direct data collection was also performed by collecting physical data in the location of shape of the fishing boat used and the power required in one ship.

There are six designs are made by varying the length of the arm by considering the shape of the construction of the fishing boat chart (Table 1). Device design made different with varying Arm Lengths. The lengths of Arm 1 and 2 are 2-4 m and 2-5 m respectively.

Table 1. Device designs with varying arm lengths

\begin{tabular}{ccc}
\hline Design & Arm 1 $(\mathrm{m})$ & Arm 2 $(\mathrm{m})$ \\
\hline DESIGN 1 & 2.0 & 5.0 \\
DESIGN 2 & 2.0 & 4.0 \\
DESIGN 3 & 3.0 & 4.0 \\
DESIGN 4 & 3.5 & 3.5 \\
DESIGN 5 & 4.0 & 3.0 \\
DESIGN 6 & 4.0 & 2.0 \\
\hline
\end{tabular}

The technical calculation required to get power value on the fishing boat chart, and then calculate the power of each design of the generator that can generate on the fishing boat chart. The amount of power generated by each device can be calculated as [14-15]: buoyancy by equation (1), weight by equation (2), force produced at $F_{2}$ due to weight by equation (3), distance of $S_{2}$ due to wave height by equation (4), number of rotations by equation (5), torque by equation (6), and power produced by equation (7).

$$
\begin{aligned}
& F_{a}=\rho_{c .} \cdot V_{c} \cdot g \\
& W=m \cdot g \\
& F_{1} \cdot L_{1}=F_{2} \cdot L_{2} \\
& S_{2} \cdot L_{1}=S_{1} \cdot L_{2} \\
& n_{1}=\frac{s_{2}}{k_{1}} \\
& T=r \cdot F \\
& P=T \cdot n \cdot 2 \pi
\end{aligned}
$$

Figure 2 shows the design of oscillating wave energy power generator on fishing boat lift nets [12]. The design consists of parts such as: buoy mechanism (1), lever mechanism (2), flywheel (3), generator (4), fishing boat (5), and spring for oscillator (6).

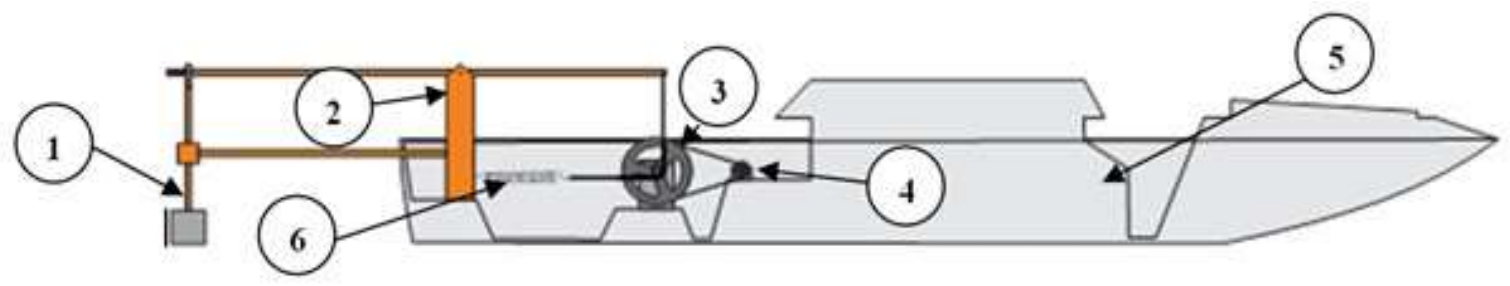

Figure 2. Oscillating wave energy power generator on fishing boat lift nets 


\section{RESULTS AND DISCUSSION}

Table 2 shows the wave height data in the water of Pajalele, Pinrang regency [16]. The result showed that the wave height minimum of $0.75 \mathrm{~m}$ and $1.50 \mathrm{~m}$ of its maximum. The wave travel time is irregular that estimated at two seconds per wave.

Figure 3 shows the number of rotations $(n)$ that the tool can produce, given the wave height $\left(S_{1}\right)$ and the variation in Arm length 1 and Arm length 2. At the minimum wave height of $0.75 \mathrm{~m}$, DESIGN 1 can produce $447.85 \mathrm{rpm}$; DESIGN 2 can produce $358.28 \mathrm{rpm}$ (n). While DESIGN 3, DESIGN 4, DESIGN 5, and DESIGN 6 respectively are $238.85 \mathrm{rpm}, 179.14 \mathrm{rpm}, 134.36 \mathrm{rpm}$ and $85.57 \mathrm{rpm}$. At the maximum wave height of $1.5 \mathrm{~m}$, DESIGN 1 can produce $895.7 \mathrm{rpm}$ (n) rotations. DESIGN 2 can produce $716.56 \mathrm{rpm}$. As well as DESIGN 3, DESIGN 4, DESIGN 5, and DESIGN 6 can rotate $477.71 \mathrm{rpm}, 358.28 \mathrm{rpm}, 168.71 \mathrm{rpm}$ and $179.14 \mathrm{rpm}$, respectively. Thus, it can be concluded that the higher the wave, the more rotations it can be generated by the tool. Other than that, it can also be influenced by the length of Arm design.

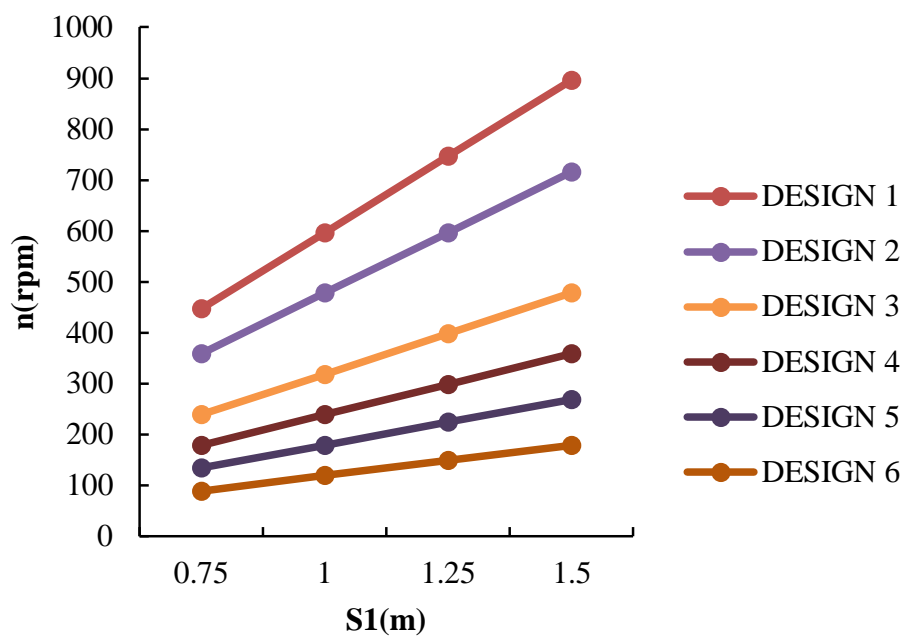

Figure 3. Results wave height $\left(S_{1}\right)$ versus number of rotation $(n)$

Table 2. Wave height data for the waters of Pajalele, Pinrang Regency

\begin{tabular}{ccc}
\hline Date & Time & Wave Height $(\mathrm{m})$ \\
\hline 01-Jan-16 & 00 & 0.75 \\
20-Jan-16 & 00 & 0.75 \\
01-Feb-16 & 00 & 0.75 \\
20-Feb-16 & 00 & 0.75 \\
01-Mar-16 & 00 & 1.50 \\
20-Mar-16 & 00 & 1.00 \\
01-Apr-16 & 00 & 0.75 \\
20-Apr-16 & 00 & 1.00 \\
01-May-16 & 00 & 0.75 \\
20-May-16 & 00 & 0.75 \\
01-Jun-16 & 00 & 1.25 \\
20-Jun-16 & 00 & 1.50 \\
01-Aug-16 & 00 & 1.25 \\
20-Aug-16 & 00 & 1.00 \\
01-Sep-16 & 00 & 1.50 \\
20-Sep-16 & 00 & 1.50 \\
01-Oct-16 & 00 & 1.00 \\
20-Oct-16 & 00 & 1.25 \\
01-Nov-16 & 00 & 0.75 \\
20-Nov-16 & 00 & 1.25 \\
01-Dec-16 & 00 & 0.75 \\
20-Dec-16 & 00 & 0.75 \\
\hline
\end{tabular}

Figure 4 shows the amount of torque at the pulley $3\left(T_{3}\right)$, given the wave height and the variation of the Arm length number 1 and Arm number 2. At the minimum wave height of $0.75 \mathrm{~m}$, DESIGN 1 produces 25.41 Nm Torque at pulley 3, DESIGN 2 produces 6.87 Nm torque on pulley 3, while DESIGN 3, DESIGN 
4, DESIGN 5 and DESIGN 6 respectively are $12.59 \mathrm{Nm}, 9.36 \mathrm{Nm}, 6,07 \mathrm{Nm}$, and $4.72 \mathrm{Nm}$. At the maximum wave height of $1.5 \mathrm{~m}$, the DESIGN 1 produces $25.33 \mathrm{Nm}$ torque at pulley 3, DESIGN 2 produces $16.76 \mathrm{Nm}$ torque at pulley 3, while DESIGN 3, DESIGN 4, DESIGN 5, and Design 6 respectively produce $12.44 \mathrm{Nm}$, $9.16 \mathrm{Nm}, 5.77 \mathrm{Nm}$, and $4.35 \mathrm{Nm}$. The wave height graph does not show significant effect towards the amount of torque at the pulley 3 , but the the amount of torque at the pulley 3 is affected by the length of Arm $1\left(L_{1}\right)$ and $\operatorname{Arm} 2\left(L_{2}\right)$ of the tool.

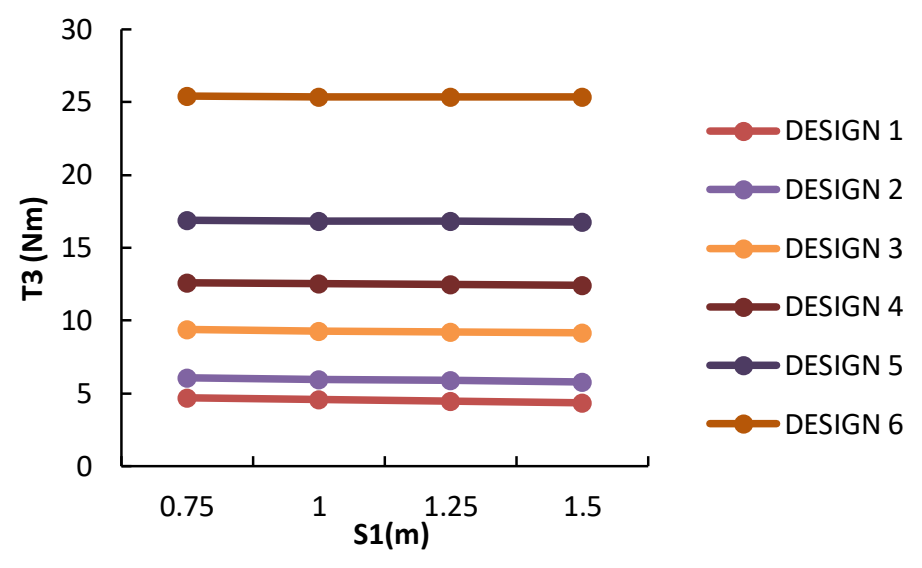

Figure 4. Results of wave height $\left(S_{1}\right)$ versus torque at pulley $3\left(T_{3}\right)$

Figure 5 shows the amount of power generated $(P)$, given the wave height and the variation in Arm length 1 and Arm 2. At the minimum wave height of $0.75 \mathrm{~m}$, DESIGN 1 generates $13277.8125 \mathrm{~W}$ of power; DESIGN 2 generates $13657.5 \mathrm{~W}$ of power, while DESIGN 3, DESIGN 4, DESIGN 5, and DESIGN 6 respectively are $14032.5 \mathrm{~W}, 14163.75 \mathrm{~W}, 14237.5781 \mathrm{~W}$ and $14290.3125 \mathrm{~W}$. The added value of power of each Arm length variation is not too much, so from the direct variation of the Arm length does not significantly affect the power. But indirectly the number of rotations greatly affects the power. At the maximum wave height of $1.5 \mathrm{~m}$, DESIGN 1 generates $24446.25 \mathrm{~W}$ of power; DESIGN 2 produces $25965 \mathrm{~W}$ of power, while DESIGN 3, DESIGN 4, DESIGN 5, and DESIGN 6 respectively are $27465 \mathrm{~W}, 27990 \mathrm{~W}$, $28285.3125 \mathrm{~W}$, and $28496.25 \mathrm{~W}$. The wave's height can greatly affect the magnitude of power. In addition, the torque on pulley 3 and the number of rotations also greatly affect the amount of power that can be generated.

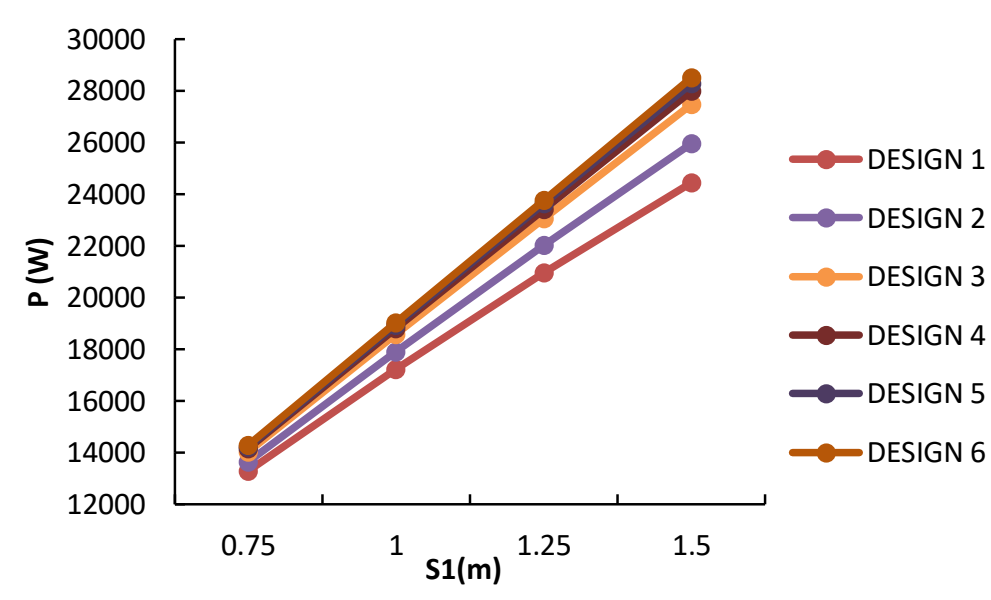

Figure 5. Results of wave height $\left(S_{1}\right)$ versus generated power $(P)$ 
Table 3 and 4 are showing the values of power generated for each design at minimum and maximum wave heights respectively. Because the desired power is at least 13,500 W, then DESIGN 1 is not suitable for minimum wave conditions at the site; though the maximum wave height can reach the desired power. In addition, the magnitude of $S_{2}$ or distance due to wave height must be known by looking at the Table 5 .

Table 5 and 6 are showing the $S_{2}$ values or distances that occur due to wave height. Since the boat's height is only $1.55 \mathrm{~m}$, the $S_{2}$ value should be much smaller so that the up and down motion of the Arm does not affect the boat body. From Table 5, only DESIGN 1 and DESIGN 2 are unusable. However, at maximum wave height as in Table 6, only DESIGN 5 and DESIGN 6 can be used. It can therefore be inferred from the four tables above that only DESIGN 5 and DESIGN 6 are suitably functional for installation on fishing boats in the waters of Tonyaman.

Table 3. Power generated by generator at minimum wave height $(0.75 \mathrm{~m})$

\begin{tabular}{cccc}
\hline DESIGN & $L_{1}(\mathrm{~m})$ & $L_{2}(\mathrm{~m})$ & Power $(\mathrm{W})$ \\
\hline 1 & 2.0 & 5.0 & 13277.8 \\
2 & 2.0 & 4.0 & 13657.5 \\
3 & 3.0 & 4.0 & 14032.5 \\
4 & 3.5 & 3.5 & 14163.7 \\
5 & 4.0 & 3.0 & 14237.6 \\
6 & 4.0 & 2.0 & 14290.3 \\
\hline
\end{tabular}

Table 4. Power generated at maximum wave height $(1.5 \mathrm{~m})$

\begin{tabular}{cccc}
\hline DESIGN & $L_{1}(\mathrm{~m})$ & $L_{2}(\mathrm{~m})$ & Power $(\mathrm{W})$ \\
\hline 1 & 2.0 & 5.0 & 24446.2 \\
2 & 2.0 & 4.0 & 25965.0 \\
3 & 3.0 & 4.0 & 27465.0 \\
4 & 3.5 & 3.5 & 27990.0 \\
5 & 4.0 & 3.0 & 28285.3 \\
6 & 4.0 & 2.0 & 28496.2 \\
\hline
\end{tabular}

Table 5. Size of movement in comparison to wave height $\left(S_{2}\right)$ at minimum Wave Height $(0.75 \mathrm{~m})$

\begin{tabular}{cccc}
\hline DESIGN & $L_{1}(\mathrm{~m})$ & $L_{2}(\mathrm{~m})$ & $\boldsymbol{S}_{\mathbf{2}}(\mathbf{m})$ \\
\hline 1 & 2.0 & 5.0 & 1.9 \\
2 & 2.0 & 4.0 & 1.5 \\
3 & 3.0 & 4.0 & 1.0 \\
4 & 3.5 & 3.5 & 0.8 \\
5 & 4.0 & 3.0 & 0.6 \\
6 & 4.0 & 2.0 & 0.4 \\
\hline
\end{tabular}

Table 6. Size of movement in comparison to wave height $\left(S_{2}\right)$ at maximum Wave Height (1.5 m)

\begin{tabular}{cccc}
\hline DESIGN & $L_{1}(\mathrm{~m})$ & $L_{2}(\mathrm{~m})$ & $\boldsymbol{S}_{\mathbf{2}}(\mathbf{m})$ \\
\hline 1 & 2.0 & 5.0 & 3.8 \\
2 & 2.0 & 4.0 & 3.0 \\
3 & 3.0 & 4.0 & 2.0 \\
4 & 3.5 & 3.5 & 1.5 \\
5 & 4.0 & 3.0 & 1.1 \\
6 & 4.0 & 2.0 & 0.8 \\
\hline
\end{tabular}

\section{CONCLUSIONS}

Based on wave height data for the period of January to December 2016 and data on the structure of local fishing boats, the oscillating wave energy power generators most suitable for use in the local lift net fishing boats in the Tonyaman Waters as replacements for diesel engines to power lighting are DESIGN 5 $\left(L_{1}=4 \mathrm{~m}\right.$ and $\left.L_{2}=3 \mathrm{~m}\right)$ and DESIGN $6\left(L_{1}=4 \mathrm{~m}\right.$ and $\left.L_{2}=2 \mathrm{~m}\right)$. These were the only two of the tested designs that produced enough energy to power the lights in both the lowest and the highest wave conditions.In the lowest wave condition, DESIGN 5 generates power of 14,237.58W and DESIGN 6 generates power of $14,290.31 \mathrm{~W}$ of power. While at the highest wave condition, DESIGN 5 and DESIGN 6 generate power of $28,285.31 \mathrm{~W}$ and $28,496.25 \mathrm{~W}$, respectively. 


\section{REFERENCES}

[1] M. A. Marfai, D. W. Tyas, I. Nugraha, A. Fitriatul'Ulya, and W. Riasasi, "The Morphodynamics of Wulan Delta and Its Impacts on the Coastal Community in Wedung Subdistrict, Demak Regency, Indonesia," Journal of Environmental Protection, vol. 7, pp. 60-71, 2016.

[2] D. N. Sugianto, Kunarso, M. Helmi, and I. Alifdini, "Wave Energy Reviews in Indonesia," International Journal of Mechanical Engineering and Technology (IJMET), vol. 8, issue 10, pp. 448-459, 2017.

[3] D. Anggraini, M. I. Al Hafiz, A. F. Derian, and Y. Alfi, "Quantitative Analysis of Indonesia Ocean Wave Energy Potential Using Oscillating Water Column Energy Converter," Matter: International Journal of Science and Technology, special issue, vol. 1, issue 1, pp. 228-239, 2015.

[4] Agency for the Assessment and Application of Technology, "Indonesia Energy Outlook 2017," ed: PTSEIK-BPPT Publishing, 2017, p. 20.

[5] P. T. D. Rompas, H. Taunaumang, and F. J. Sangari, "A Numerical Design of Marine Current for Predicting Velocity and Kinetic Energy," Indonesian Journal of Electrical Engineering and Compuetr Science," vol. 5, no. 2, pp. 401-409, 2017.

[6] P. T. D. Rompas and J. D. I. Manongko, "A Numerical Modeling for Study Marine Current in the Manado Bay, North Sulawesi," Telkomnika (Telecommunication Computing Electronics and Control), vol. 16, no. 1, pp. 18-24, 2018.

[7] R. Waters, "Energy from Ocean Waves: Full Scale Experimental Verification of a Wave Energy Converter," Acta Universitatis Upsaliensis, Digital Comprehensive Summaries of Uppsala Dissetations from the Faculty of Science and Technology 580, 2008, $130 \mathrm{pp}$.

[8] R. Manasseh, S. A. Sannasiraj, K. L. Mclnnes, V. Sundar, and P. Jalihal, "Integration of Wave Energy and Other Marine Renewable Energy Sources with the Needs of Coastal Societies," The International Journal of Ocean and Climate Systems, vol. 8, no. 1, pp. 19-36, 2017.

[9] F. D. Wijaya, Sarjiya, and M. R. P. Sugita, "Optimizing Tri-Core Permanent-Magnet-Linear-Generator DirectDrive Wave-Energy-Conversion System Design for Sea Wave Characteristics in South Coast Yogyakarta,“ International Journal of Electrical and Computer Engineering (IJECE), vol. 7, No. 2, pp. 610-618, 2017.

[10] A. F. O. Falcon and J. C. C. Henriques, "Oscillating-Water-Column Wave Energy Converter and Air Turbines: A Review," Renewable Energy, vol. 85, pp. 1391-1424, 2016.

[11] J. C. C. Henriques, J. C. C. Portillo, L. M. C. Gato, R. P. F. Gomes, D. N. Ferreira, and A. F. O. Falcao, "Design of Oscillating-Water-Column Wave Energy Converters with an Application to Self-Powered Sensor Buoys,” Energy, vol 112, pp. 852-867, 2016.

[12] R. L. E. Putri, M. Sarwoko, A. Rusdinar, and K. B. Adam, "Design and Implementation of Ocean Wave Power Plant Using DC Generator System to Charging Battery Electric Boat," in E-Proceeding of Engineering, 2016, vol. 3, no. 1, pp. 91-98.

[13] Sinu KJ and G. Ranganathan, "A Novel Hydro Powered Online Power Converter for Marine Lighting Applications," vol. 9, no. 1, pp. 15-19, 2018.

[14] Soebyakto, "Economic Evaluation of Power Waves at the Beach Tegal," Jurnal Teknosains, vol. 6, no. 1, pp. 1-6, 2016.

[15] R. Sandro, Arnudin, A. Tussadiah, R. M. Utamy, N. Pridina, and L. N. Afifah, " Study of Wind, Tidal Wave and Current Potential in Sunda Strait as an Alternative Energy," Energy Procedia, vol. 47, 242-249, 2014.

[16] Badan Meteorologi Klimatologi dan Geofisika (BMKG) Stasiun Maritim Makassar, "Prakiraan Rata-rata Harian Tinggi Gelombang Laut Wilayah Perairan Pajalele Sualwesi Selatan,” 2016. 